\title{
SPINNING DROPLETS - A CONSPICUOUS LAPILLI-SIZE STRUCTURE IN KAMAFUGITIC DIATREMES OF SOUTHERN GOIÁS, BRAZIL
}

\author{
TEREZA CRISTINA JUNQUEIRA-BROD*, JOSE AFFONSO BROD*, ROBERT N. THOMPSON** \& SALLY A. GIBSON***
}

\begin{abstract}
RESUMO SPINNING DROPLETS - UMA ESTRUTURA TAMANHO LAPILLI, CONSPÍCUA EM DIATREMAS KAMAFUGITICOS DO SUL DE GOIAS, BRASIL Lavas, diques e diatremas ocorrem na regiao de Águas Emendadas, sul do estado de Goias, formando parte da Provincia Ignea Rio Verde-Ipora, de idade Cretaceo Superior. Foram reconhecidos diversos tipos de fragmentos juvenis na matriz das brechas de facies diatrema, incluindo armoured lapilli, frozen droplets e spinning droplets. Este trabalho descreve os spinning droplets e propoe um modelo para sua gerafao em diatremas.

Palavras-chave: spinning droplets, kamafugito, diatrema, lapilli

ABSTRACT Kamafugitic lavas, dykes and diatremes occur in the Aguas Emendadas Region, southern Goias, forming part of the Late-Cretaceous Rio Verde-Ipora Igneous Province. A variety of lapilli-sized juvenile fragments occurring in the matrix of diatreme-facies breccias were recognised. These include armoured lapilli, frozen droplets and spinning droplets. This work describes the spinning droplets and proposes a model for their formation in diatrene environments.
\end{abstract}

Keywords: spinning droplets, kamafugite, diatreme, lapilli

INTRODUCTION In southern Goias, a number of Late-Cretaceous volcanic, pyroclastic and intrusive alkaline rocks are emplaced close to the northern border of the Parana Basin. These rocks were collectively called the Rio Verde-Ipora Igneous Province (RVIIP) by Almeida (1983). Among other petrographic types, occurrences of kamafugites in the province have been reported by Danni (1985), Danni \& Caspar (1994) and Sgarbi et al (1998).

Diatremes, dykes and lava flows with kamafugitic affinity occur in the Aguas Emendadas region, located between the towns of Amorinopolis and Montividiu (Junqueira-Brod 1998, Junqueira-Brod etal. 1999). The diatremes are infilled mostly by breccias, containing fragments of variable origin, shape and size (up to $3 \mathrm{~m}$ in diameter). According to their origin these fragments can be classified as cognate, accidental, accessory and juvenile (Cas \& Wright 1987). The cognate fragments range from highly porphyritic kamafugites to cumulates of pyroxene and olivine. They are non-vesicular rocks, crystallised from the magma prior to eruption (autoliths). Accessory and accidental fragments correspond to rocks from the conduit wall and diatreme roof respectively, caught by the magma during ascent and eruption (xeno- liths and xenocrysts). They are represented by granites, gneiss, amphibolites, schists and quartzites from the Pre-Cambrian basement, sandstones from the Parana Basin and other alkaline rocks, mainly leucitites of the RVIIP. Juvenile fragments are samples of the erupting magma and their shape and size are directly associated to the physical behaviour of the magma during ascent and eruption. They have kamafugitic composition and may be vesiculated. Such a wide variety of fragments in the breccias is the combined result of complex processes involved in the formation of the diatremes (Junqueira-Brod et al. 1999).

The breccia matrix consists of a polilithic lapilli tuff (JunqueiraBrod 1998) containing the same types of fragments above, together with pyroxene, olivine and alkali feldspar crystals and ash. The juvenile fragments are dominant, vary in size from ash to lapilli, and are usually rounded. Three main types of juvenile fragments are recognised (Junqueira-Brod 1998): armoured lapilli, frozen droplets and spinning droplets (Fig. 1). The scope of this work is to describe the spinning droplets, a peculiar lapilli-sized fragment whose origin appears to be closely linked with the magma composition and the diatreme environment.

\begin{tabular}{|c|c|c|c|c|}
\hline \multicolumn{5}{|c|}{ LAPILLI SIZE STRUCTURES } \\
\hline structure & size & shape & description & model \\
\hline $\begin{array}{l}\text { armoured } \\
\text { lapilli }\end{array}$ & lappilli & $\begin{array}{l}\mathrm{v} \\
\mathrm{a} \\
\mathrm{r} \\
\mathrm{i} \\
\mathrm{a} \\
\mathrm{b} \\
\mathrm{l} \\
\mathrm{e}\end{array}$ & $\begin{array}{l}\text { presence of a core, composed of a lithic or } \\
\text { crystal fragment (Pre-Cambrian rocks, } \\
\text { sandstone, alkaline rocks, alkali feldspar), } \\
\text { and a rim made of ash. }\end{array}$ & \\
\hline $\begin{array}{l}\text { "frozen } \\
\text { droplets" }\end{array}$ & $\begin{array}{l}\mathrm{v} \\
\mathrm{a} \\
\mathrm{r} \\
\mathrm{i} \\
\mathrm{a} \\
\mathrm{b} \\
\mathrm{b} \\
\mathrm{e}\end{array}$ & $\begin{array}{l}\mathrm{v} \\
\mathrm{a} \\
\mathrm{r} \\
\mathrm{i} \\
\mathrm{a} \\
\mathrm{b} \\
\mathrm{l} \\
\mathrm{e}\end{array}$ & $\begin{array}{l}\text { composed by microphenocrysts of pyroxene } \\
\text { and olivine, vesicles filled with carbonate and } \\
\text { a glassy groundmass. The shape is variable } \\
\text { but with rounded contours. }\end{array}$ & \\
\hline $\begin{array}{l}\text { "spinning } \\
\text { droplets" }\end{array}$ & lappilli & spherical & $\begin{array}{l}\text { presence of a core composed of phlogopite, } \\
\text { pyroxene, olivine or a lithic fragment. The } \\
\text { rim comprises a microcystalline groun- } \\
\text { dmass and a great number of micro- } \\
\text { phenocrysts orientated concentrically around } \\
\text { the core. }\end{array}$ & \\
\hline
\end{tabular}

Figure 1 - Main characteristics of the juvenile lapilli-size fragments found in the Águas Emendadas diatremes 


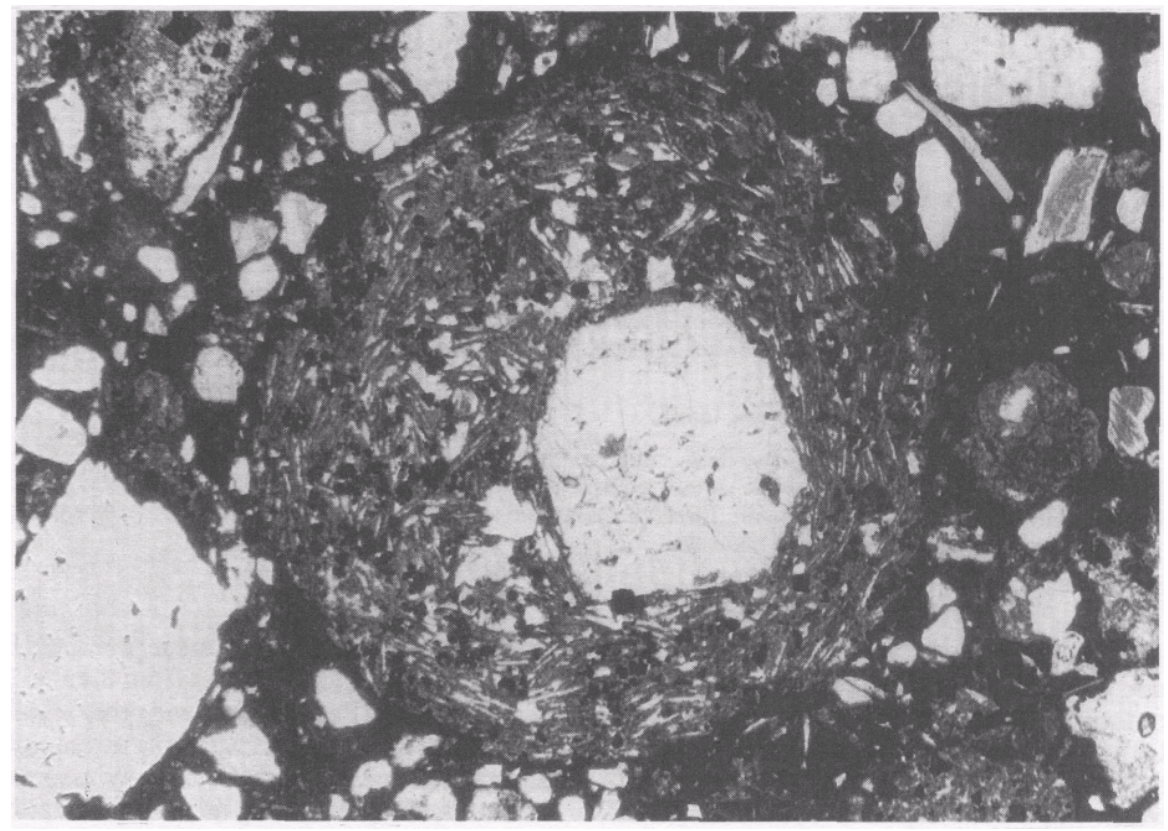

Figure 2- photomicrograph of a spinning droplet. The particle is composed of a pyroxene core and a concentrically oriented, microporphyritic rim. Field of view is $5 \times 3.5 \mathrm{~mm}$. Plane-polarized light.

SPINNING DROPLETS The name "spinning droplet" was proposed by Junqueira-Brod (1998) to describe a type of spherical juvenile fragment, up to $12 \mathrm{~mm}$ in diameter, composed by a crystal core and a densely micropo/phyritic rim with concentrically-oriented structure, occuring in the Águas Emendadas diatremes (Fig. 2).

Somewhat similar structures have been described in other alkaline rocks, such as carbonatites, kimberlites and melilitites, and have been given different names, such as: "pelletal lapilli", "spherical lapilli", "tuffisitic lapilli" and "concentrically shelled lapilli" (e.g. Clement 1973, Dawson 1980, Clement \& Skinner 1985, Mitchell 1986, Keller 1989, Dawson et al. 1992, Stoppa \& Lavecchia 1992, Stoppa \& Lupini 1993, Mitchell 1995, Stachel et al. 1995, Stoppa 1996, Stoppa \& Principe 1997, Stoppa \& Woolley 1997, Kurszlaukis \& Lorenz 1997, Lorenz \& Kurszlaukis 1997). However, all the above classifications carry limitations derived either from the definition itself or from the misinterpretation of processes involved in the genesis of these structures. The name spinning droplets is applied exclusively on a textural sense, avoiding any size and/or origin implications (Junqueira-Brod 1998).

Macroscopically, the spinning droplets resemble armoured lapilli, but can be easily distinguished from the latter under the microscope, by the presence of a rim composed of oriented microphenocrysts plus devitrified glass, instead of ash. Furthermore, they are invariably spherical, whilst armoured lapilli can mimic the shape of their core. The third type of juvenile lapilli, frozen droplets, are distinguished by their lack of concentric orientation, a smaller microphenocryst/groundmass ratio than the spinning droplets, frequent absence of crystal nucleous and a more variable shape, although always outlined,by rounded contours.

The cores of the spinning droplets can be made of phlogopite, pyroxene or olivine, in this order of abundance, usually as a single euhedral crystal. Rarely, fragments of cumulates are also found. Together, phlogopite and pyroxene make up the core of about $80 \%$ of the studied particles. The crystal core is situated almost invariably in centre of the particle, although some degree of eccentricity is present in rare individuals. The size of the cores is limited to less than half the diameter of the particle, in most cases.

The rim is formed by a dense aggregate of concentrically oriented prismatic microphenocrysts, immersed in a glassy groundmass. The microphenocrysts are represented by pyroxene and probably melilite, with subordinate oxides, olivine, carbonate and phlogopite.

DISCUSSION Structures such as the spinning droplets are often found in diatremes (e.g. Clement \& Skinner 1985, Mitchell 1995, Lorenz \& Kurszlaukis 1997, Kurszlaukis \& Lorenz 1997, JunqueiraBrod 1998). Therefore, their origin must be'somehow linked with processes occurring in diatreme environments. Mitchell (1995) gives a summary of the ideas about diatreme formation in association with kimberlitic magmatism, while Lorenz \& Kurszlaukis (1997) extend the studies for carbonatite-related volcanism. The latter authors, among others, consider two possible alternative processes, relevant to the formation of diatremes: a magmatic and a phreatomagmatic model.

The magmatic model involves rapid exsolution of a volatile phase, with the particles being transported in a gas-liquid fluidized system, resulting in a "cold" emplacement. MacCallum (1985) studied fluidization experimentally and suggests that it is an important process in the formation of breccia pipes. A turbulent movement is required to produce a well-mixed system, as is the case in diatreme facies. In this context, the spinninng droplets would be formed inside the conduit, during the ascent of the fluidized mixture, in a simillar way as proposed by Clement (1973) and later by Dawson (1980).

The phreatomagmatic eruptions are the result of hot magma interacting explosively with a body of cold water, a process also known as fuel-coolant interaction (e.g. Sheridan \& Wohletz, 1983; Cas \& Wright, 1987). Authors who adopt this model to explain the formation of diatremes and associated deposits include Lorenz (1979), Zimanowski et al. (1997), Kurszlaukis \& Lorenz (1997) and Lorenz \& Kurslaukis (1997). In this model the fragmentation of the magma is not taken into consideration. The origin of the spinning droplets would have to be explained by magma adhering to a previously crystallised nucleous, due to surface tension, followed by rotation of the droplets during transport (Mitchell 1995). In the rocks that form the Aguas Emendadas diatremes there is no strong evidence of magma-water interaction. Therefore it is unlikely that a phreatomagmatic component contributed for the formation of the spinning droplets.

An alternative model for the formation of particles like the spinning droplets is presented by Stoppa (1996), but it requires, by definition, a mantle xenolith/xenocryst as a core for each lapillus and a magma with carbonatitic-melilititic affinity (Stoppa 1996, Stoppa \& Woolley 1997). In this model the magma comes directly from the mantle at high velocity and the liquid adheres to a xenolith core. The cores found in lapilli from Aguas Emendadas region seem to be crystals formed an underlying the magma chamber and entrained by magma prior to the eruption. There is no evidence linking them with a mantle origin. Association with carbonatitic magma can neither be proved, nor ruled out at the present stage.

The model envisaged here for the formation of the spinning droplets in kamafugitic diatremes is an adaptation of the process suggested by Clement (1973) and Dawson (1980), and later summarised by Mitchell (1995). It is proposed that the spinning droplets are formed by the rotation of magma droplets during ascent in a fluidized system. This mechanism requires fragmentation and high velocity of the rising magma or mixture, in order to form and spin the droplets. Most of the existing models presume fragmentation of the magma through volatile 

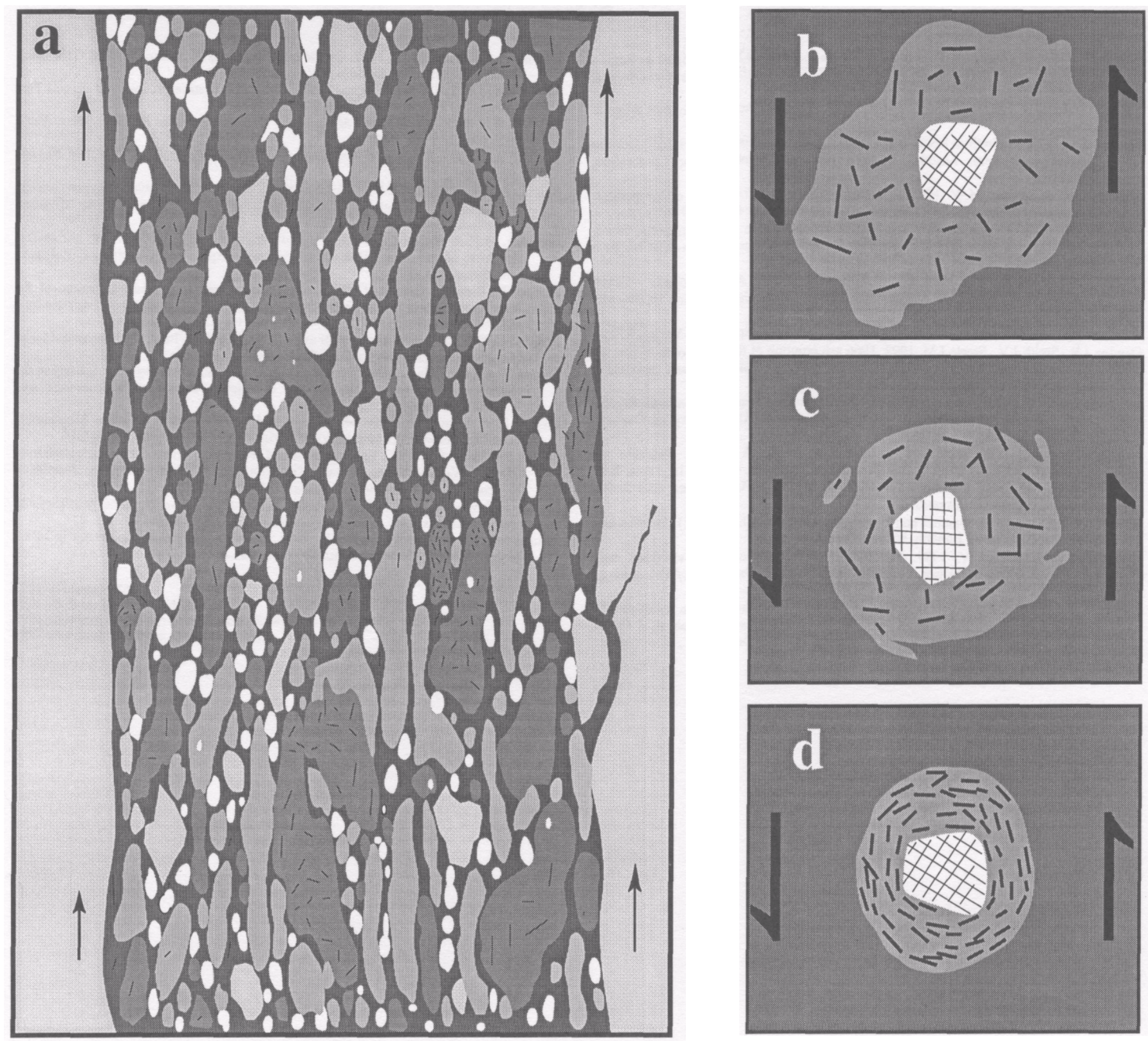

Figure 3 - Schematic model for the processes involved in the formation of spinning droples. The microporphyritic magma droplets spin in the conduit, during the ascent of a fluidized mixture, orienting the microphenocrysths around the crystal core and becoming spherical in shape, a) detail of the rising fluidized mixture in the conduit, it is important to notice the high degree of fragmentation of the mixture, b) first stage of the spinning droplets formation, a magma droplet starts to spin, c) while spinning, the droplet loses part of the liquid fraction concentrating microphenocrysts. d) the rotation, combined with the increment in the microphenocrysts/groundmass ratio, result in the final, spherical, concentric particle.

exsolution and/or interaction with cold water during rapid ascent from the mantle source to the surface. However, field, petrographic and chemical evidence from Aguas Emendadas suggests that a number of magma chamber processes occurred during magma evolution (Junqueira-Brod 1998). These include fractionation, with the formation of cumulates, and mixing of at least two different magmas. It is suggested here that magma fragmentation was triggered within the magma chamber, by magma mixing, volatile exsolution (high vesiculation), liquid immiscibility or a combination of two or more of these processes. In this scenario, the mixture rising from the chamber to surface would consist of several phases of contrasting composition and density, including droplets of partially crystallised magma. The density contrast during the rise of the fluidized mixture at high velocity, would result in relative movement between the different phases, favouring the rotation of the magma droplets in localised domains (Fig. 3). During rotation there must be the concomitant action of two processes: a) the liquid phase within the spinning droplets must be fluid enough to allow the phenocrysts to be concentrically oriented, b) some of this liquid fraction must be lost, probably by a spinning-induced filter pressing process, to explain the much higher microphenocryst/groundmass ratio of the spinning droplets, in comparison with the frozen droplets. The combined action of rotation and partial loss of liquid would favour the achievement of the nearly-spherical shapes (see Fig. $3 b$ to d). When they reach the surface the droplets are already shaped. Particles such as the frozen droplets are likely to represent the non-spun equivalents of spinning droplets, generated in a lower energy, latestage eruption.

A detailed study of the spinning droplets, including experimental modelling and further comparison with similar spherical structures elsewhere is required, in order to achieve a full understanding of their origin.

Acknowledgement to prof. Othon H.Leonardos e Maria das Gramas Viana who provides great help during the fieldwork. We are greatful to two anonymous referees for the comments and corretions. 


\section{References}

Almeida F.F.M. 1983. Relacoes Tectonicas das Rochas Alcalinas Mesozóicas da Regiao Meridional da Plataforma Sul-Americana. Revista Brasileira de Geociencias, 13(3): $139-158$

Cas R. \& Wright J.V. 1987. Volcanic Successions: Modern and Ancient. London, Alien \& Unwin, $528 \mathrm{p}$

Clement C.R. 1973. Kimberlites from the Kao Pipe, Lesotho. In Nixon, P.H. (ed.) Lesotho Kimberlites. Maseru, Lesotho, Lesotho National Development Corporation, $110-121$

Clement C.R. \& Skinner M.W. 1985. A textural-genetic classification of kimberlites Transactions of the Geological Society of South Africa, 88:403-409

Danni J.C.M. 1985. Rochas da s6rie kamafugftica na regiao de Amorin6polis, Cola's. ContribuifSes \& geologia e a petrografia -Nucleo de Minas Gerais- SBGM, Belo Horizonte, 5-13

Danni J.C.M. \& Caspar J.C. 1994. Qufmica do katungito de Amorin6polis - Goias: Contribuifao ao estudo do magmatismo kamafugitico. Geochimica Brasiliensis 8:119-134

Dawson J.B. 1980. Kimberlites and Their Xenoliths. New York, Springer-Verlag, 252 p.

Dawson J.B., Smith J.V., Steele I.M. 1992. 1966 ash eruption of the carbonatite volcano Oldoinyo Lengai: mineralogy of lapilli and mixing of silicate and carbonatite magmas. Mineralogical Magazine, 56:1-16

Junqueira-Brod T.C. 1998. Cretaceous Alkaline Rocks from the Águas Emendadas Region, Golds, Central Brazil. Dept. of Geological Sciences, University of Durham, Durham, U.K., MSc Thesis, 161p.

Junqueira-Brod T.C., Thompson R.N., Gibson S.A., Brod J.A. 1999. Volcanic and Pyroclastic Processes at the Aguas Emendadas Diatreme, GoiSs. In: Lima, E.F.; Wildner, W. (eds.) I Simp6sio sobre Vulcanismo e Ambientes Associados, Gramado, Boletim de Resumos, 58

Keller J. 1989. Extrusive carbonatites and their significance. In Bell, K. (ed.) Carbonatites: genesis and evolution. London, Unwin Hyman, 70-88

Kurszlaukis S. \& Lorenz V. 1997. Volcanological features of low-viscosity melt: carbonatitic Gross Brukkaros Volcanic Field, Namibia. Bulletin of Volcanology, 58: 421431

Lorenz V. 1979. Phreatomagmatic origin of olivine melilite diatremes in Swabian Alb, Germany. In: Boyd, F.R.; Meyer, H.O.A. (eds.), American Geophysical Union, Second International Kimberlite Conference, Washington, D.C., Proceedings, 1:354-363
Lorenz V. \& Kurszlaukis S. 1997. On the last explosions of carbonatite pipe G3b, Gross Brukkaros, Namibia. Bulletin of Volcanology, 59:1-9

McCallum M.E. 1985. Experimental Evidence for Fluidization Processes in Breccia Pipe Formation. Economic Geology, 80:1523-1543

Mitchell R.H. 1986. Kimberlites: Mineralogy, Geochemistry and Petrology. New York, NY, Plenum Press, 442p.

Mitchell R.H. 1995. Kimberlites, Orangeites and Related Rocks. New York, NY, Plenum Press, 41 Op.

Sgarbi P.B.A., Clayton R.N., Toshiko K.M., Caspar J.C. 1998. Oxygen isotope thermometry of Brazilian potassic volcanic rocks of kamafugitic affinities. Chemical Geology 146:115-126

Sheridan, M.F, \& Wohletz, k.h. 1983. Hydrovolcanism: basic considerations and review In: M.F. Sheridan and F. Barberi (Editors), Explosive Volcanism. J. Volcanol. Geotherm. Res., 17:1-29.

Stachel T., Brey G., Lorenz V. 1995. Carbonatite magmatism and fenitization of the epiclastic caldera-fill at Gross-Brukkaros (Namibia). Bulletin of Volcanology, 57:185-196

Stoppa F. 1996. The San Venanzo maar and tuff ring, Umbria, Italy: eruptive behaviour of a carbonatite-melilitite volcano. Bulletin of Volcanology, 57:563-577

Stoppa F. \& Lavecchia G. 1992. Late Pleistocene ultra-alkaline magmatic activity in the Umbria-Latium region (Italy): An overview. Journal of Volcanology and Geothermal Research, 52:277-293

Stoppa F. \& Lupini L. 1993. Mineralogy and Petrology of the Polino Monticellite Calciocarbonatite (Central Italy). Mineralogy and Petrology, 49:213-231

Stoppa F. \& Principe C. 1997. Eruption style and petrology of a new carbonatitic suite from the Mt. Vulture Southern Italy: The Monti'cchio Lakes Formation. Journal of Volcanology and Geothermal Research, 78:251-265

Stoppa, F. \& Woolley A.R. 1997. The Italian carbonatites: field occurrence, petrology and regional significance. Mineralogy and Petrology, 59:43-67

Zimanowski B., Buttner R, Lorenz V 1997. Premixing of magma and water in MFCI experiments. Bulletin of Volcanology, 58: 491-495.

Manscrito A-1091

Recebido em 05 de maio de 1999 Revisao dos autores em 05 de junho de 1999 Revisao aceita em 10 de junho de 1999 